\title{
Impact of Land Use/Cover Changes on the Flow of the Zarqa River in Jordan
}

\author{
Maisa'a W. Shammout ${ }^{1 *}$, Khaldoun Shatanawi ${ }^{2}$, Jawad Al-Bakri ${ }^{3}$, \\ Mahmoud M. Abualhaija ${ }^{4}$ \\ 1 Water, Energy and Environment Center, The University of Jordan, Amman 11942, Jordan \\ 2 School of Engineering, The University of Jordan, Amman 11942, Jordan \\ 3 School of Agriculture, The University of Jordan, Amman 11942, Jordan \\ ${ }^{4}$ Water, Energy and Environment Center, The University of Jordan, Amman 11942, Jordan \\ * Corresponding author's e-mail:m.shammout@ju.edu.jo
}

\begin{abstract}
This paper investigated the impact of land use/cover changes on the flow of the Zarqa River in Jordan over a period of twenty-eight years. The land use/cover maps were derived using a set of medium spatial images with full scenes for the years 1989, 2002, 2011 and 2017. These images correspond to the river flow data for the same hydrological rainy seasons. The component of the river flow consists of the base-flow, flood and contribution of effluent from treatment plants. Base-flow was separated from hydrographs and effluent contribution was obtained. Runoff coefficient was determined as the ratio of flood volume to rainfall volume. The land use/cover maps were classified as urban fabrics, bare rocks, open rangelands and bare soils, agricultural areas, agro-forestry, and water bodies. During the study period, urban areas increased from $4.87 \%$ to $16.14 \%$, and agricultural areas increased from $21.69 \%$ to $31.66 \%$. The areas of rangelands and bare soil decreased from $34.91 \%$ to $22.57 \%$ and bare rocks from $35.98 \%$ to $27.57 \%$, respectively. The increase in urban and agricultural areas resulted in runoff coefficient improvement from $1.89 \%$ in $1989 / 1990$ to $2.72 \%$ for $2016 / 2017$. The results could be useful for planners and decision makers for future flow management in the Zarqa River Basin. The approach and results of this study confirm the findings of similar studies for land and water management.
\end{abstract}

Keywords: river flow, flood, land use/cover changes, runoff coefficient, planners and decision makers

\section{INTRODUCTION}

The land use/cover information is the basic pre-requisite for land and water resource utilization, conservation and management. It is used to protect the water resources necessary for sustaining human life (Demir et al. 2007). The information on land use/cover are available today in the form of thematic maps, where earth features such as water, urban, forest, exhibit typical spectral response pattern that enables for target identification, such as assessing the impact of land use/ cover changes on river flow (Cook 1945; Gautam et al. 2000; Shammout 2003). Land use/cover change and climate variability are two major factors controlling the hydrological responses, but the dominant role in the hydrological responses is played by the land use/cover change (Berihun et al. 2019). It is widely known that changes in landuse/cover, such as conversion of forest land into cropland or grazing land, and urbanization, can increase surface runoff (Chow et al. 1988).

Land use/cover change is a major challenge facing the global environment (Kates and Torrie 1998). This change in land use/cover, when coupled with climate change, could potentially lead to an increased risk of flooding in urban catchments. The influence of land use/cover change on surface runoff has been investigated in many studies. They examined the impacts of land use/ 
cover changes on floods, e.g. in Australia (Chen and Yu 2013), and in south-eastern United States (Nagy et al. 2011) as well as studied the water resources and land use and cover, indicating that the forest removal leads to more variable flow. In Italy, the results of land use change impact on flooding areas showed an increase in flood peak and a decrease of the rangelands, forests, and bare lands, indicating a good correlation between flooding areas and land use changes (Apollonio et al. 2016). In the city of Ghent, the results showed that grasslands contribute the most to storm water runoff reduction, and forests controlled the lowest runoff (Li et al. 2020). (Shanableh et al. 2018) confirmed that the expansion of built areas progressively increased the impervious land cover in the coastal city of Sharjah, and significantly increased the runoff coefficient.

In developing countries, the rapid increase in population pressure has pronounced effects on the land use/cover dynamics, mainly through deforestation aimed at increasing agricultural production (Maitima et al. 2009). These changes are causing alterations of the land surface and also have a great impact on hydrological processes such as surface flow, groundwater recharge, infiltration, interception, and evapotranspiration (Costa et al. 2003; Shammout et al. 2013). Most of the studies agree that the expansion of agricultural lands and the growth of urban areas at the expense of vegetation cover and forest significantly increase the surface runoff potential in a given watershed. (Yin et al. 2017) showed that the water resources subjected to land use/cover and climate changes, affected surface runoff differently between decades due to the combined effects of land use/cover and climate changes. The impact of urbanization through assessing the relationship between urbanization, runoff, floods and rainwater harvesting provides a basis for developing sustainable urban storm water management practices for the cities. Hence, proper land management may increase the amount of surface storage, rate of infiltration, and capacity of the soil to store water. Without proper land use management, the alterations of the land surface on hydrological processes will be continued and mainly exhibited in river flow. Moreover, the amount of surface storage, rate of infiltration, and capacity of the soil to store water will be also decreased (Chow et al. 1988; Shammout et al. 2013; Chen et al. 2017; Xu et al. 2017).
This study was conducted for the Zarqa River Basin (ZRB). It investigated the impact of land use/cover changes of ZRB on the flow of the Zarqa River over a period of twenty-eight years. This basin is located in Jordan, where surface water resources in Jordan are mainly scattered between 15 basins. One of the major basins is ZRB and it is well recognized as one of the most important basins with respect to its economic, social and agricultural importance. It is the second main tributary to Jordan River. ZRB is the most affected area suffering from several quality and quantity water problems. These problems are due to the scarcity of water which is a result of the wide fluctuations in annual rainfall and climate change, population growth, urbanization, and inappropriate land uses which resulted in watershed degradation. Accordingly, management tools should be adopted by planners to minimize this degradation. For this purpose, the translation of available real historical data of land use/cover images into responses of change for the river flow is essential for understanding, assessing, and managing the ZRB. The specific objectives were (1) to analyse the land use/cover distributions of the years 1989, 2002, 2011 and 2017, (2) to assess the impact of land use/cover changes on the responses of the river flow for the hydrological rainy seasons; 1989/1990, 2001/2002, 2010/2011, and $2016 / 2017$, and (3) to compare the change in runoff coefficient as a result of land use/cover changes over the targeted years.

\section{METHODOLOGY}

\section{Study Site}

The Zarqa River Basin (ZRB) drains an area of $4120 \mathrm{~km}^{2}$, about $95 \%$ of which is within Jordan and only $5 \%$ is in Syria. The basin extends from the Syrian city of Salkhad in Jebal al-Arab with an elevation of 1,460 m to south of Amman. Administratively, ZRB is located in five governorates, namely; Amman, Balqa'a, Zarqa, Jerash, and Mafraq. The ZRB hosts more than 50\% of Jordan's population (10.5 millions). The basin discharges its water at the confluence of the Zarqa River with the Jordan River at an elevation of about $-350 \mathrm{~m}$. The streamflow of the Zarqa River is impounded at King Talal Dam (KTD), the largest Dam in Jordan, South-West of Jerash town. There are several 
wadis draining in the ZRB, such as Wadi Dhuleil, and Wadi Zaatari. The runoff gauge station at Jerash Bridge on the Zarqa River is the only gauge station in the whole basin (Al-Qaisi 2015) which has the continuous long recorded database and possibly sufficient to be suitable for flood evaluation, as it is located at the entrance of the KTD from the east (Shammout 2003). Figure 1 shows the Zarqa River Basin.

The soils of the ZRB differ widely according to the rainfall and climate. The basin is mainly located in northern highlands dissected limestone and the north Jordan basalt plateau (Al-Bakri 2008). In the west, the prevailing soil textures are clay and clay loams. Toward the east, the soil becomes more immature with silty loam to loamy in texture with very high carbonate content. These soils have weak structure and suffer from low infiltration rate, resulting from the presence of surface crust. Land and water use in the ZRB has undergone considerable changes. Recently, the expansion of Amman and the surrounding towns has been enormous, thus reducing the grazing land and fertile agricultural lands between Amman and other towns. The expansion was developed into a large urban conglomerate. In the north and north western parts, the ZRB is capable of supporting forests and agricultural activities. Natural forests occur in the mountainous part and agriculture within the basin is divided into agroforestry, rain-fed orchards and olives, field crops as well as irrigated agriculture. Historically, irrigation was practiced on the banks of the river, while during the last three decades, it expanded in the northern and middle parts of the basin, particularly in the Mafraq governorate where the irrigated areas nearly tripled during 1990-2014 (Al-Bakri 2008). The total irrigated area of the basin reached 18 thousand ha in year 2014 (AlBakri 2016). This resulted in increasing the demand and pressure on the limited groundwater resources of the basin.

The basin includes four municipal wastewater treatment plants (TPs), namely, Khirbet es-Samra
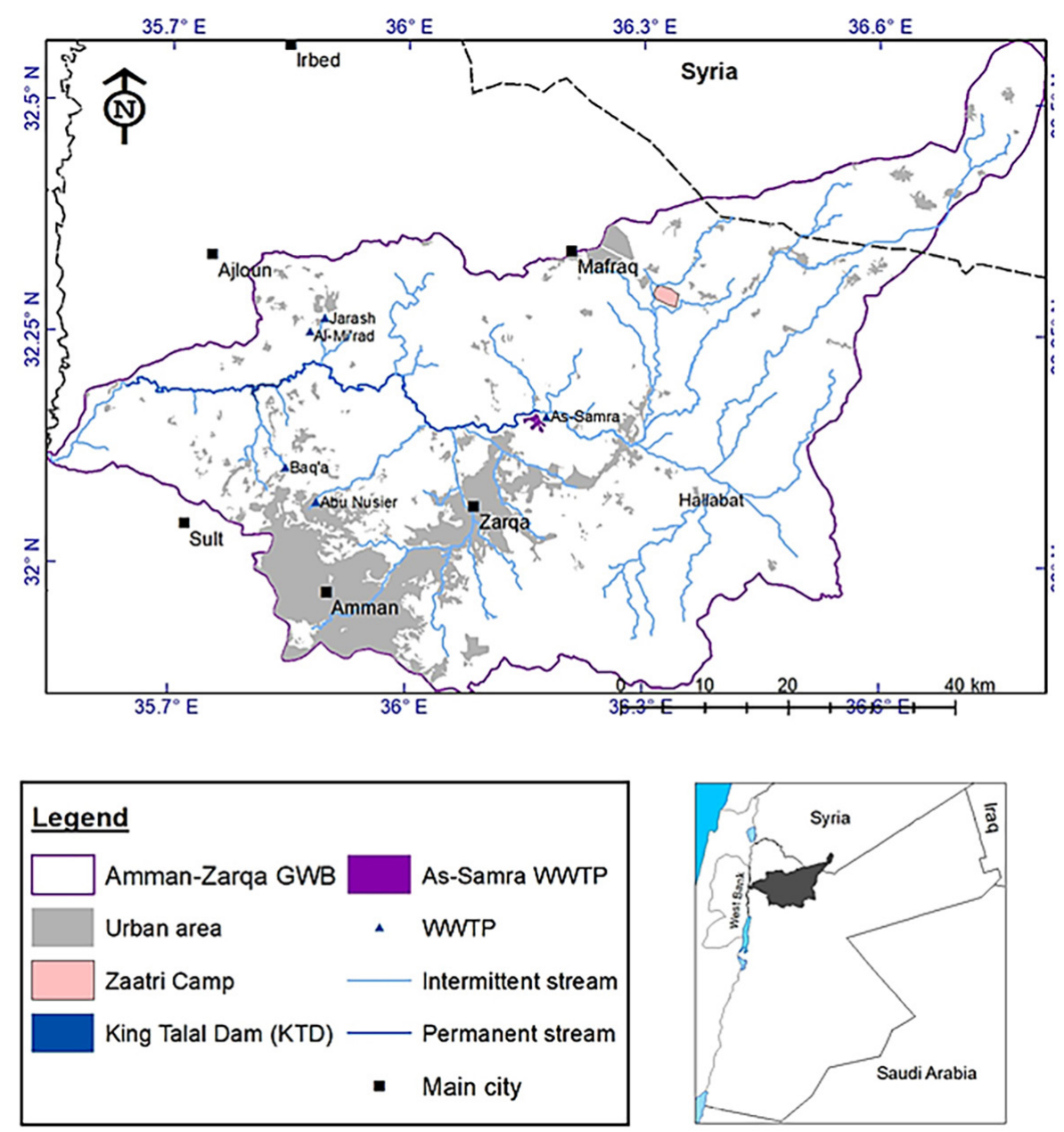

Figure 1. The Zarqa River Basin 
Treatment Plant (KSTP), Abu Nusair, Baqa'a, and Jerash. KSTP is the largest wastewater treatment plant located in the ZRB. The treated wastewater discharged from KSTP to Wadi Dhuleil flows downstream to join the Zarqa River near Sukhna. The volume of effluent discharged from the TPs to the Zarqa River is expected to reach $180 \mathrm{MCM}$ by the year 2025, which will lead to the needed of a set of strategies for the expansion, sanitation and storm water management (Heller et al. 2014). The water system in ZRB is characterized by complex characteristics, where its flow mixed with treated effluents from treatment plants and finally stored in KTD, which is located at the outlet of the basin where the dam's water is used for irrigation in the Jordan valley. Only 50 MCM surface fresh water is pumped to the basin from the Jordan Valley for domestic use and the groundwater from different basins is transferred to meet the growing domestic demand (Shatanawi and Shammout 2011). The heavy utilization of the water resources of the ZRB has resulted in reducing the base flow of the Zarqa River from $5 \mathrm{~m}^{3} / \mathrm{s}$ to less than $1 \mathrm{~m}^{3} / \mathrm{s}$ and the discharge of the springs reduces from an of average $317 \mathrm{MCM} /$ year prior to 1985 to less than $130 \mathrm{MCM} /$ year after 2000 (Shammout 2003).

\section{Assessment of land use/cover changes}

A set of medium spatial resolution images of Landsat Thematic Mapper (TM), Enhanced Thematic Mapper Plus (ETM+) and Opera-tional Land Imager (OLI) images were used to derive land use/cover maps of the basin. The dataset included full scenes for the years 1989, 2002, 2012 and 2017 for the path/row 173/38 and 174/38. These images corresponded to the same hydrological rainy seasons, except the $1989 / 1990$ season which was only based on the 1989 image instead of the 1990, which was not available. The selected datasets were cloud free images acquired during March - May, when natural vegetation and rain-fed crops are usually at their peak growth. The dataset was mainly downloaded from the official website of Landsat 8 (http://earthexplorer. usgs.gov) at no cost. The data used for mapping land use/cover included the visible and the near infrared (NIR) bands with $30 \mathrm{~m}$ spatial resolution. Various image processing techniques were applied to prepare the images for digital and visual interpretation of land use/cover. This included the transformation of images to derive normalized difference vegetation index (NDVI), visual interpretation for urban areas and forests, mosaicking of output layers and clipping of the images to the borders of the study area.

The first step of deriving the land use/cover maps was the derivation of NDVI layers to represent all vegetated areas in the basin. The second step was the use of visual interpretation of images in order to derive layers of agroforestry in the high rainfall areas and urban areas all over the basin. The method of visual interpretation was preferred over the digital classification techniques to avoid classification errors that might result from spectral mixing at the $30 \mathrm{~m}$ spatial resolution. Following this step, different functions within the geographic information system (GIS) were applied to append the layers derived from the visual interpretation onto the layers of NDVI. The results of land use/cover mapping for year 2017 were verified using field visits and the highresolution images of Google Earth. The historical map of 1989 was verified and corrected using the hardcopy topographic maps of the Royal Jordanian Geographic Centre (RJGC), while the maps of 2002 and 2011 were verified by the maps produced by the previous research carried out on the basin (Al-Bakri et al. 2013). The land use/cover maps included seven classes that were selected to serve the objective of this study, while ensuring high accuracy of mapping as no subdivisions for the main classes were included in the maps. The land use/cover classes are continuous urban fabrics, discontinuous urban fabrics, bare rocks, agricultural areas, agroforestry, open rangelands and bare soils, and water bodies.

\section{The flow responses to land use/cover changes}

Four hydrological rainy seasons were considered in this study, the first one represents an average rainy season in 1989/1990 (from 1 October 1989 to 30 September 1990), the second year represents a wet rainy season in 2001/2002 (from 1 October 2001 to 30 September 2002), the third year 2010/2011(from 1 October 2010 to 30 September 2011), and the fourth season 2016/2017 (from 1 October 2016 to 30 September 2017. All the data of rainy seasons related to the river flow (base-flow + flood) records of the only gauging station at the New Jerash Road Bridge are available on a daily basis $\left(\mathrm{m}^{3} / \mathrm{sec}\right)$. This station is the most 
essential gauge with a complete flow record and is used for assessing the river flow amounts. The daily Zarqa River flow data of the gauging station was obtained from the Ministry of Water and Irrigation (MWI, 1989-2017) for the selected rainy seasons. Similarly, the daily effluents from KSTP were also acquired from the records of the Ministry of Water and Irrigation (MWI 1989-2017).

The hydrographs of daily flow in $\mathrm{m}^{3} / \mathrm{sec}$ were constructed in order to separate the baseflow from the flood flow. This was carried out by using the above mentioned flow data. The total base-flow in the Zarqa River consists of one portion of KSTP reaching the gauging station, and the second portion, it is the flow that would exist in the stream without contribution of direct flood (runoff). The separation of the total base-flow was done using the straight line method for each event (Chow et al. 1988), from which the time point of direct surface flood begins to the point where normal baseflow resumes. Between these points, surface flood and base-flow can be separated. This was done by using the stream flow hydrograph in Excel. Once the beginning and ending of each flood were even, the total base-flow were determined and their values were recorded. The actual base-flow was separated from the portion of KSTP effluent. This portion is an equal from effluent of KSTP effluent minus the portion of effluent that has been used upstream of the gauging station for irrigation. The flood flows were determined by integrating the areas of each hydrographs above the base-flow and summing them all to determine the annual flood for each targeted year.

The rainfall data from 10 gauge stations was obtained from Ministry of Water and Irrigation that allow studying the responses of the Zarqa River flow. The ZRB was outlined to define its boundaries, drainage network and outlet using the Digital Elevation Model (DEM). There are 33 rainfall gauges in the ZRB. Only 10 of them have long records over the years from 1989 to 2017. For the selected rain gauges, Thiessen weighted average method was used (Chow et al. 1988) to determine the influence of each rain gauge to the whole basin. Average rainfall was computed according to the following equation (Chow et al. 1988):

$$
\text { Average Rainfall }=\frac{1}{A} \sum_{j=1}^{J} A_{j} P_{j}
$$

where: J: gauges,

$A j$ : gauge area,

$P j$ : rainfall recorded at $j$ th gauge, $A: \sum A j$.

The computed area in $\mathrm{km}^{2}$ for each gauge by applying the Thiessen method; Balama $390 \mathrm{~km}^{2}$, Jerash $291 \mathrm{~km}^{2}$, Zarqa $566 \mathrm{~km}^{2}$, Suweileh $61 \mathrm{~km}^{2}$, Amman Hussein College $308 \mathrm{~km}^{2}$, Rumeimin $39 \mathrm{~km}^{2}$, Qasr el Hallabat $718 \mathrm{~km}^{2}$, Um el Jimal $475 \mathrm{~km}^{2}$, Wadi Es-Sir $21 \mathrm{~km}^{2}$, and Um el Quttein $640 \mathrm{~km}^{2}$. The total area of delineated ZRB till the gauging station at the New Jerash Road Bridge is about $3509 \mathrm{~km}^{2}$. The rainfall-runoff relationship for each rainy season; 1989/1990, 2001/2002, 2010/2011, and $2016 / 2017$ in terms of runoff coefficients were determined by dividing direct flood volume by the total corresponding rainfall volume above the gauging station (Chow et al. 1988). In order to study the effect of land use/cover on the Zarqa River flow, each class of the land use/ cover was compared with the runoff coefficient.

\section{RESULTS AND DISCUSSION}

\section{Land use/cover changes}

Land use/cover maps of the years 1989, 2002, 2011, and 2017 (Figure 2) showed that the ZRB was dynamic in terms of land use character. Table 1 summarizes the percentages of each land use/cover class during the period of 1989-2017. The map of 1989 showed that the main land use/ cover classes were distributed as: $35.98 \%$ bare rocks, $34.91 \%$ open rangelands and bare soils, $21.69 \%$ agricultural areas, $4.87 \%$ urban, $2.28 \%$ agroforestry and $0.3 \%$ of water bodies. By the year 2017, land use/cover classes were distributed as: $27.57 \%$ bare rocks, $22.57 \%$ open rangelands and bare soils, $31.66 \%$ agricultural areas, $16.14 \%$ urban, $1.79 \%$ agroforestry and less than $0.3 \%$ of water bodies (Table 1 ). The main trends of the land use change were expansion in both urban and agricultural areas and the recession of 
open rangelands and non-cultivated areas. These results were confirmed in the previous findings in the basin and in similar areas in Jordan (AlBakri et al. 2013).

In comparison with the land use distribution from 1989 to 2017, the land use changes have shown that continuous urban fabrics class has increased by $12.23 \%$, and agricultural areas class has increased by $9.97 \%$. On the other hand, there has been a reduction in agroforestry by $0.5 \%$, and a reduction in open rangelands and bare soils by $12.34 \%$. Part of the changes in agricultural areas

a)

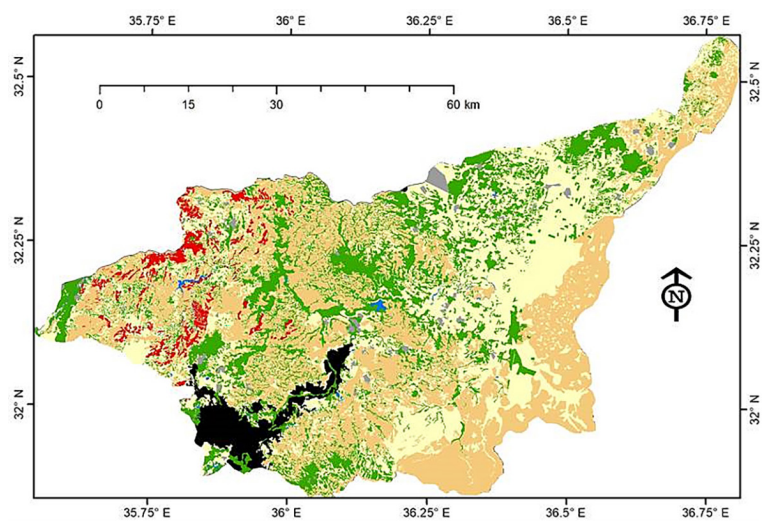

c)

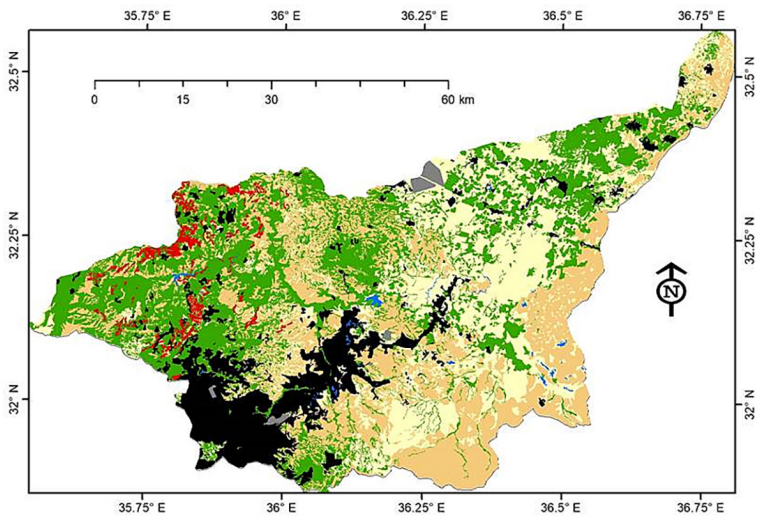

could be attributed to the differences in rainfall amounts and distribution among the four seasons. This would be expected under the Mediterranean environment, which had variability in rainfall during the season and among the seasons. Urbanization in the basin was seen as an important change that would reflect the water supply and demand. Urbanization was mainly on the expenses of agricultural areas in the high rainfall zones, particularly in the area of Amman, while expansion of agricultural areas was on the expenses of open rangelands in suburban areas. The previous

b)

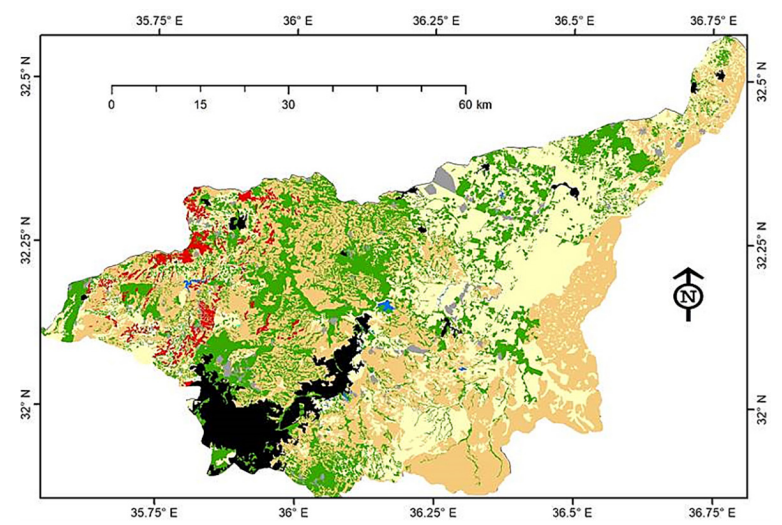

d)

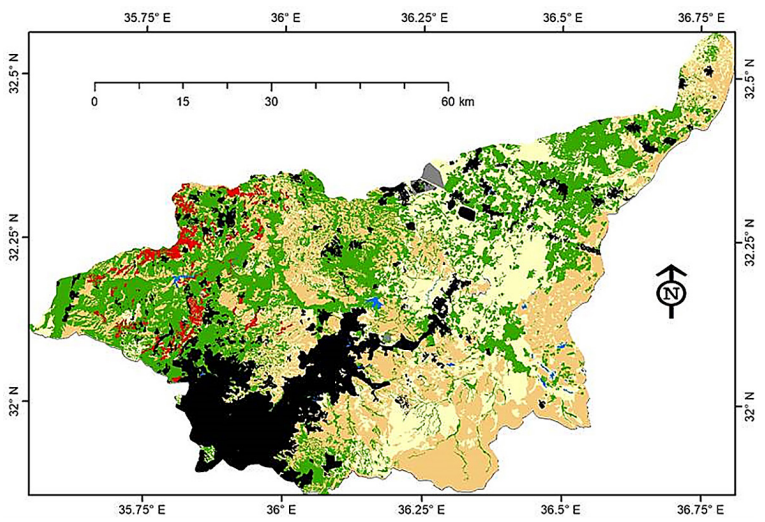

Figure 2 Land use/cover maps of the Zarqa River Basin during 1989-2017: (a) 1989; (b) 2002; (c) 2011; (d) 2017

Table 1. Land use/cover distribution in \% of the Zarqa River Basin for the years 1989, 2002, 2011 and 2017

\begin{tabular}{|l|c|c|c|c|c|}
\hline \multicolumn{1}{|c|}{ Land Use Distribution (\%) } & 1989 & 2002 & 2011 & 2017 & \% Change 1989-2017 \\
\hline Continuous urban fabrics & 3.52 & 6.06 & 12.43 & 15.76 & +12.23 \\
\hline Discontinuous urban fabrics & 1.35 & 2.13 & 0.52 & 0.38 & -0.97 \\
\hline Bare rocks & 35.98 & 36.73 & 28.84 & 27.57 & -8.41 \\
\hline Open rangelands and bare soils & 34.91 & 29.02 & 24.56 & 22.57 & -12.34 \\
\hline Agricultural areas & 21.69 & 23.72 & 31.49 & 31.66 & +9.97 \\
\hline Agroforestry & 2.28 & 2.04 & 1.82 & 1.79 & -0.49 \\
\hline Water bodies & 0.27 & 0.30 & 0.33 & 0.27 & 0.00 \\
\hline Total & 100 & 100 & 100 & 100 & \\
\hline
\end{tabular}


research in the basin showed that irrigation has expanded in the low rainfall zones in the north, north east and in the middle parts of the basin (A1-Bakri et al. 2016). These trends of land use change resulted in over pumping of groundwater and the increased amounts of treated wastewater effluents of KSTP

\section{Flow responses and land use/cover changes}

Figure 3. shows the flow responses of the Zarqa River for the rainy seasons 1989/1990, 2001/2002, 2010/2011 and 2016/2017. Figure 4 shows the effluent of Khirbet es-Samra Treatment Plant (KSTP) for (a) 1989/1990, (b) 2001/2002, (c) 2010/2011 and (d) 2016/2017. On the basis of the land use change distribution, the values of flow amount generated have been affected accordingly, as shown in Figure 3. This is indicated scientifically for the basins concerning their land uses and flow responses (Bakir and Xingnan 2008). In comparison with the water bodies

a)

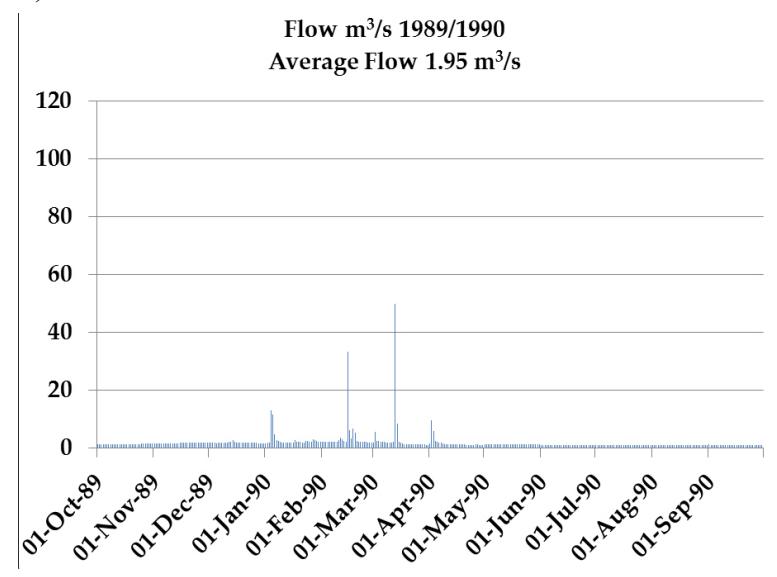

c)

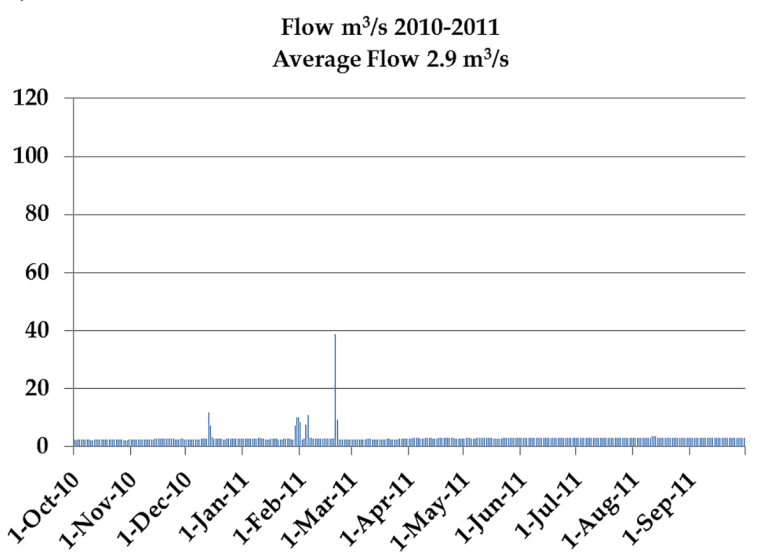

since 1989 till 2017, there has been no considerable change, whereas the direction of flow change was clearly observed and considerable in the Basin. Table 2 shows the average rainfall, average river flow gauged, average KSTP effluent, reuse of reclaimed water upstream gauging station, contribution of reclaimed wastewater to river flow, average river base-flow, average river flood, and runoff coefficient for the years 1989/1990, 2001/2002, 2010/2011 and $2016 / 2017$, respectively. The flow has been increasing, reaching about $1.95 \mathrm{~m}^{3} / \mathrm{s}$ in the year $1989 / 1990,3.09 \mathrm{~m}^{3} / \mathrm{s}$ in the year $2001 / 2002$, $2.9 \mathrm{~m}^{3} / \mathrm{s}$ in the year $2010 / 2011$, and $3.67 \mathrm{~m}^{3} / \mathrm{s}$ in the year 2016/2017. Generally, the trends of land use change were in favour of increasing flow due to urbanization and degradation of vegetation and soils in the basin. The increase in flow, however, would not compensate for the increased demand resulting from irrigation and urbanization and therefore, the problem of water scarcity would increase in the future, as indicated by the

b)

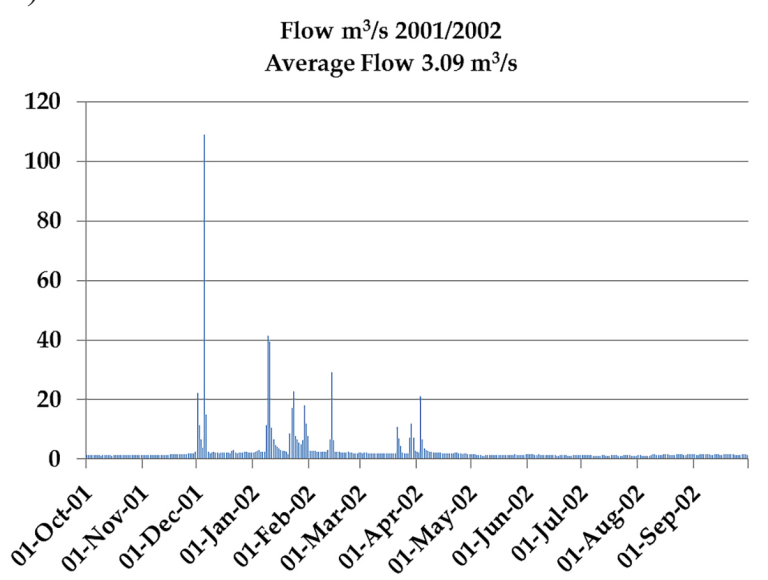

d)

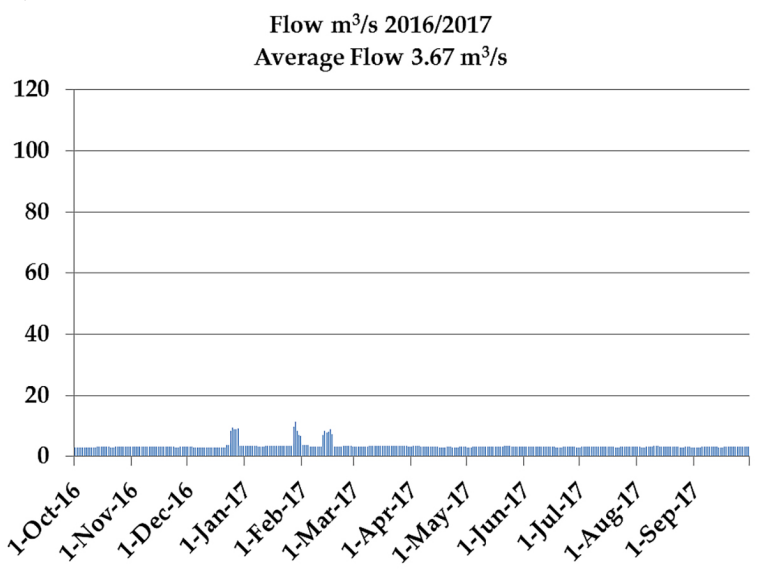

Figure 3. The flow responses of the Zarqa River for the rainy seasons 1989/1990, 2001/2001, 2010/2011 and 2016/2017: (a) Flow of 1989/1990 (b) Flow of 2001/2002 (c) Flow of 2010/2011 (d) Flow of 2016/2017 
a)

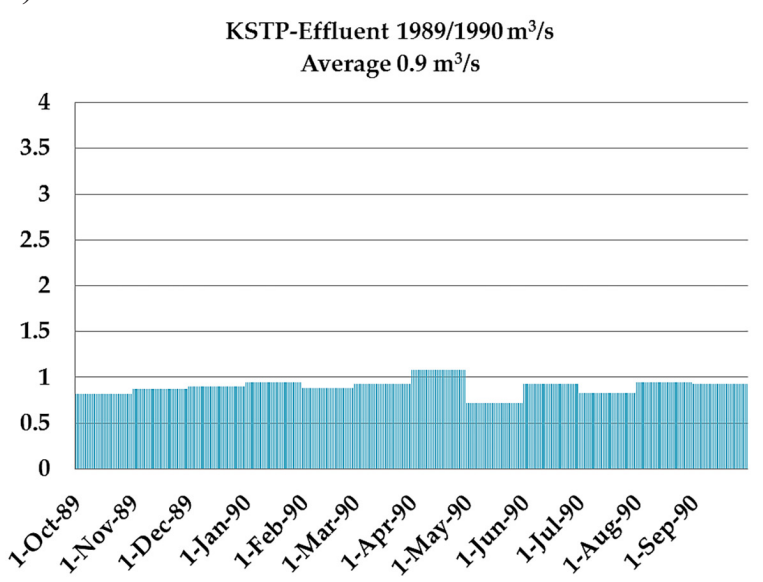

c)

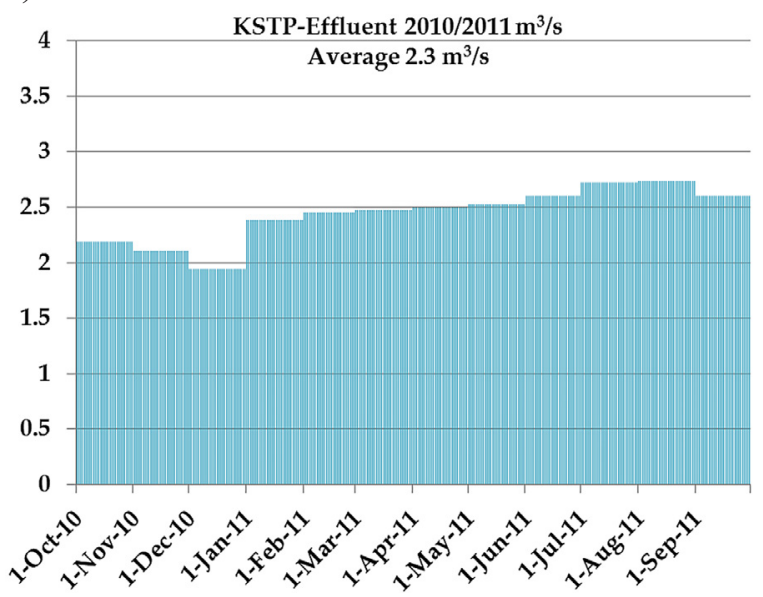

b)

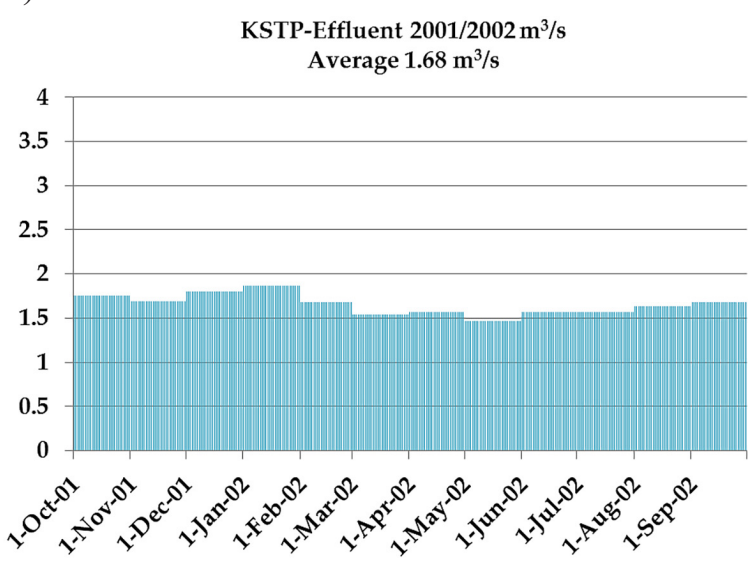

d)

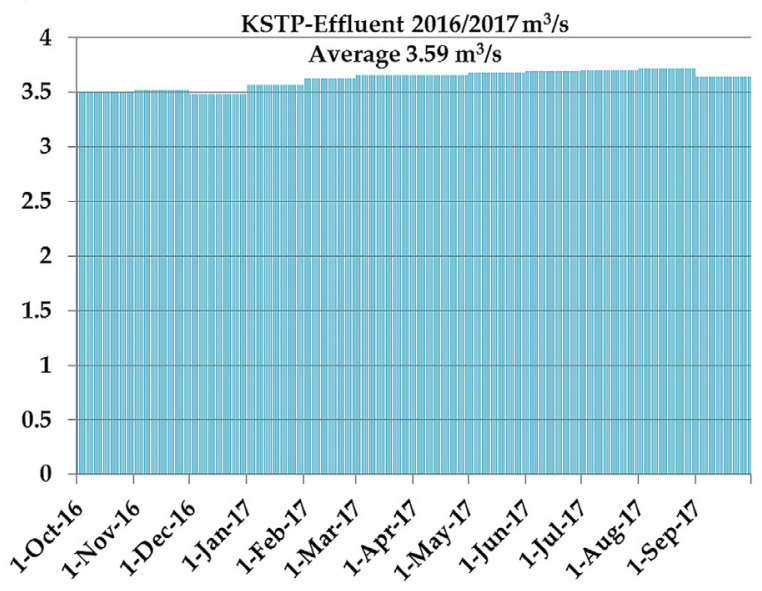

Figure 4 The effluent of Khirbet es-Samra Treatment Plant (KSTP) for (a) 1989/1990, (b) 2001/2002, (c) 2010/2011 and (d) 2016/2017

Table 2. Average rainfall, average river flow gauged, average Khirbet es-Samra Treatment Plant (KSTP) effluent, reuse of reclaimed water upstream gauging station, contribution of reclaimed wastewater in river flow, average river base-flow, average river flood, and runoff coefficient for the years 1989/1990, 2001/2002, 2010/2011 and 2016/2017

\begin{tabular}{|l|c|c|c|c|c|c|c|c|}
\hline \multicolumn{1}{|c|}{ Parameter } & \multicolumn{2}{c|}{$1989 / 1990$} & \multicolumn{2}{c|}{$2001 / 2002$} & \multicolumn{2}{c|}{$2010 / 2011$} & \multicolumn{2}{c|}{$2016 / 2017$} \\
\hline Unit & $\begin{array}{c}\mathrm{mm} \text { or } \\
\mathrm{m}^{3} / \mathrm{s}\end{array}$ & $\mathrm{MCM}$ & $\begin{array}{c}\mathrm{mm} \text { or } \\
\mathrm{m}^{3} / \mathrm{s}\end{array}$ & $\mathrm{MCM}$ & $\begin{array}{c}\mathrm{mm} \text { or } \\
\mathrm{m}^{3} / \mathrm{s}\end{array}$ & $\mathrm{MCM}$ & $\begin{array}{c}\mathrm{mm} \text { or } \\
\mathrm{m}^{3} / \mathrm{s}\end{array}$ & $\mathrm{MCM}$ \\
\hline Average rainfall & 176 & 617.6 & 244 & 856.2 & 157 & 550.9 & 180 & 631.6 \\
\hline Average river flow gauged & 1.95 & 61.5 & 3.09 & 97.5 & 2.9 & 91.4 & 3.67 & 115.8 \\
\hline Average KSTP effluent & 0.9 & 28.4 & 1.68 & 52.6 & 2.3 & 74.8 & 3.59 & 113.2 \\
\hline Reuse of reclaimed water upstream gauging station & 0.13 & 4 & 0.25 & 8 & 0.32 & 10 & 0.79 & 25 \\
\hline Contribution of reclaimed wastewater in river flow & 0.77 & 24.4 & 1.41 & 44.6 & 2.05 & 64.8 & 2.8 & 88.4 \\
\hline Average river base-flow & 0.81 & 25.4 & 0.52 & 16.3 & 0.43 & 13.4 & 0.32 & 10.2 \\
\hline Average river flood & 0.37 & 11.7 & 1.16 & 36.6 & 0.42 & 13.2 & 0.55 & 17.2 \\
\hline Runoff coefficient & & 1.89 & & 4.28 & & 2.4 & & 2.72 \\
\hline
\end{tabular}

previous studies in the basin (Al-Bakri et al. 2016). The water demand is increasing rapidly due to high population growth rates, and prolonged drought periods over the past decades which have reduced the surface and groundwater resources. However, the treated wastewater has become an ever-increasing percentage of the Zarqa River flows since the construction of the KSTP (González 2018). Therefore, due to high population growth rates, the treated wastewater constituted about $39.7 \%$ of the total flow of the Zarqa River in $1989 / 1880$, about $45.7 \%$ in 
$2001 / 2002,70.9 \%$ in $2010 / 2011$ and $76.3 \%$ in 2016/2017 as shown in Table 2.

These above-mentioned results demonstrate that the impact of land use changes on flow is an issue of considerable importance for land use management (Chow et al. 1988; Archer 2007) that can increase the amount of surface storage, rate of infiltration, and capacity of the soil to store water (Shammout et al. 2013), as water harvesting either for surface storage or for artificial recharge will assist in the sustainable management of water resources (Bakir and Xingnan 2008). Decision makers are challenged to secure more water for an increasing population and agricultural activities. They may implement the land use practices to manage the behavior of the Zarqa river flows (Farajad et al. 2017).

Table 2 shows that the years 1989/1990 and 2016/2017 are similar in rainfall amount and pattern and were considered as average years. The year 2001/2002 was considered as wet year while the year 2010/2011 was dry. The magnitude of flood depends on the timing of the rainfall. If soils are already saturated, the likelihood of flooding increases (Wrzesien and Pavelsky 2020). Part of the reclaimed water from KSTP was used upstream of the gauging station correlating $4,8,10$, and $25 \mathrm{MCM}$ for the four seasons, respectively. In 1989/1990, there was restriction on the use of reclaimed water for agriculture and therefore only $4 \mathrm{MCM}\left(0.13 \mathrm{~m}^{3} / \mathrm{s}\right)$ was used upstream of KTD. The volume of reclaimed water used for irrigation was increased to $8 \mathrm{MCM}\left(0.25 \mathrm{~m}^{3} / \mathrm{s}\right)$ in $2001 / 2002$. Due to the increase of the volume of effluent, the water authority encourages farmers to reuse the reclaimed water in irrigating forage crops and trees, fulfilling the Jordanian Standards (González 2018). This amount increased from $10 \mathrm{MCM}\left(0.32 \mathrm{~m}^{3} / \mathrm{s}\right)$ in $2010 / 2011$ to $25 \mathrm{MCM}$ $\left(0.79 \mathrm{~m}^{3} / \mathrm{s}\right)$ in 2016/2017.

As far as base-flow is concerned, it is clear from Table 2 that the base-flow has gradually dropped from $25.4 \mathrm{MCM}\left(0.81 \mathrm{~m}^{3} / \mathrm{s}\right)$ in $1989 / 1990$ to $10.2 \mathrm{MCM}\left(0.32 \mathrm{~m}^{3} / \mathrm{s}\right)$ in 2016/2017. This is because of the over-utilization of groundwater upstream and using water for irrigation (Shatanawi and Shammout 2011; Shammout et al. 2013). The base-flow in 1989/1990 was normal, originating from the discharge of the springs along the valley of the river. In the 1990s and afterwards, there was heavy pumping from the groundwater of the basin to the extent that the discharge of springs has dropped and others were completely dried. For the two average years which were similar in rainfall amount and pattern, Table 2 shows that the river flood increased from 11.7 $\operatorname{MCM}\left(0.37 \mathrm{~m}^{3} / \mathrm{s}\right)$ in $1989 / 1990$ to $17.2 \mathrm{MCM}$ $\left(0.55 \mathrm{~m}^{3} / \mathrm{s}\right)$ in $2016 / 2017$. The increase in flood may be attributed to the land use/cover change, especially the increase in urban and agricultural areas on the expense of range land and forest. This also reflects the runoff coefficient which has increased from $1.89 \%$ to $2.72 \%$ for the two years, respectively. These results confirmed the previous findings as in (Sriwongsitanon and Taesombat 2011; Li et al. 2020), where, they have shown the influence of land cover on runoff coefficient. It can be useful for land use, flood management of the river basin, and the importance for efficient scenario practices for various aspects of river flow management.

\section{CONCLUSIONS}

The Zarqa River Basin (ZRB) is under the pressure of various agricultural, industrial, and commercial activities. The water demand is increasing rapidly due to high population growth rates, and prolonged drought periods over the past decades, which have reduced the ZRB water resources. Hence, the translation of the available real historical data into the river flow responses to land use/cover changes is highly needed. This allows understanding, assessing the river flow and finding the ways towards ZRB management.

It was clearly observed that there was a direction of change of the Zarqa River flow in the basin since 1989/1990 till 2016/2017. The river flow was variable according to land use/ cover changes; the increase of urban and agricultural areas, the reduction in open rangelands and bare soil, and the reduction in agroforestry, resulted in the increase of the river flow. This also influenced the runoff coefficient. On the basis of these conditions, decision makers are challenged to secure additional water for an increasing population and agricultural activities. Nevertheless, the change in land use/cover approaches will allow the validation of future scenarios for flow management, which is an issue of significant importance that can increase the amount of surface storage, rate of infiltration, and capacity of the soil to store water. 


\section{Acknowledgments}

The authors thank all the editors and reviewers for their reviewing, suggestions, and commitment to the publication process. Special thanks to the Deanship of Scientific Research, The University of Jordan, Amman, Jordan for the support.

\section{REFERENCES}

1. Al-Bakri J.T. 2008. Soils of Jordan. In: Zdruli, P. \& Trisorio Liuzzi, G. (Eds.) Status of Mediterranean Soil Resources: Actions Needed to Support Their Sustainable Use. Mediterranean Conference Proceedings, Tunis, Tunisia 26-31 May 2007, MEDCOASTLAND Publication, IAM Bari, Italy, 368.

2. Al-Bakri J.T., Shawash S., Ghanim A., Abdelkhaleq R. 2016. Geospatial Techniques for Improved Water Management in Jordan. Water, 8, 132. DOI: $10.3390 / \mathrm{w} 8040132$

3. Al-Bakri J.T., Duqqah M., Brewer T. 2013. Application of Remote Sensing and GIS for Modeling and Assessment of Land Use/Cover change in Amman/ Jordan. Journal of Geographic Information System. 5(5), 509-519. DOI: 10.4236/jgis.2013.55048

4. Apollonio C., Balacco G., Novelli A., Tarantino E., Piccinni A.F. 2016. Land Use Change Impact on Flooding Areas: The Case Study of Cervaro Basin (Italy). Sustainability, 8, 996. DOI: 10.3390/su8100996

5. Archer D.R. 2007. The use of flow variability analysis to assess the impact of land use change on the paired Plynlimon catchments, mid-Wales. Journal of Hydrology, 347, 487-496. DOI: 10.1016/j.jhydrol.2007.09.036

6. Al-Qaisi B. 2015. Climate Change Effects on Water Resources in Amman Zarqa Basin-Jordan. International Journal of Core Engineering \& Management (IJCEM), 2(7), 52-82.

7. Bakir M. \& Xingnan Z. 2008. GIS and Remote Sensing applications for rain water harvesting in the Syrian Desert (Al-Badia), In Proceedings of the 12th International Water Technology Conference (IWTC,12), Alexandria, Egypt, March 2008.

8. Berihun M.L., Tsunekawa A., Haregeweyn N., Meshesha D.T., Adgo E., Tsubo M., Masunaga T., Fenta A.A., Sultan D., Yibeltal M., Ebabu K. 2019. Hydrological responses to land use/land cover change and climate variability in contrasting agroecological environments of the Upper Blue Nile basin, Ethiopia. Science of the Total Environment, 689, 347-365. DOI: 10.1016/j.scitotenv.2019.06.338

9. Chen W., Huang G., Zhang H., 2017. Urban storm water inundation simulation based on SWMM and diffusive overland-flow model. Water Science and Technology, 76(12), 3392-3403. DOI: 10.2166/ wst.2017.504
10. Chen Y. \& Yu B. 2013. Impacts of climate and landuse changes on floods in an urban catchment in southeast Queensland, Australia. In the Climate and Land Surface Changes in Hydrology Proceedings of H01, IAHS-IAPSO-IASPEI Assembly, Gothenburg, Sweden, July 2013 (IAHS Publ. 359, 2013).

11. Chow V.T., Maidment D.R., Mays L.W. 1988. Applied Hydrology; McGraw-Hill Book Company: New York, NY, USA.

12. Costa M.H., Botta A., Cardille J.A. 2003. Effects of large-scale changes in land cover on the discharge of the Tocantins River, Southeastern Amazonia. J. Hydrol., 283(1-4), 206-217. DOI: 10.1016/ S0022-1694(03)00267-1

13. Cook H.L. 1945. Flood Abatement by Headwater Measure. Civil Eng., 15, 127-130.

14. Demir O., Yaçinkaya M., Atasoy M., Bayrak T., Bryik C. 2007. Evaluating sustainable land use for the Değirmendere valley: A case study from northeastern Turkey. International Journal of Sustainable Development \& World Ecology, 14(6), 626-633. DOI: $10.1080 / 13504500709469760$

15. Farjad B., Pooyandeh M., Gupta A., Motamedi M., Marceau D. 2017. Modelling Interactions between Land Use, Climate, and Hydrology along with Stakeholders' Negotiation for Water Resources Management. Sustainability, 9, 2022. DOI: 10.3390/ su9112022

16. Gautam N.C., Shankar R., Raghavswamy G.V., Narasimha Rao K., Nagaraja R., Saxena M.R., Jayanthi S.C., Suesh L.S., 2000. Spatial Analysis of Land use/ Land cover over India using satellite based remote sensing techniques. India Journal of Agricultural Economics, 55(2), 19-28. DOI: 10.22004/ ag.econ. 297742

17. González A.B. 2018. The Water-Energy-Agriculture nexus in Jordan-A case study on As-Samra wastewater treatment plant in the Lower Jordan River Basin. Master of Science Thesis: TRITA-ITM-EX: 588, Stockholm. http://www.divaportal.org/smash/ get/diva2:1236635/FULLTEXT01.pdf

18. Heller L., Rodrigues L.A., Silveira R.B. 2014. Scenarios for environmental sanitation in Brazil. Water Policy, 16(3), 501-519. DOI: 10.2166/wp.2014.119

19. Kates R.W. \& Torrie R.D. 1998. Global change in local places: how scale matters. Environment, 40(2), 5-8. DOI: 10.1080/00139159809605088

20. Li L., Eetvelde V., Cheng X., Uyttenhove P. 2020. Assessing stormwater runoff reduction capacity of existing green infrastructure in the city of Ghent. International Journal of Sustainable Development \& World Ecology. DOI: 10.1080/13504509.2020.1739166

21. Maitima J.M., Mugatha S.M., Reid R.S., Gachimbi L.N., Majule A., Lyaruu H., Pomery D., Mathai S., Mugisha S., 2009. The linkages between land use 
change, land degradation and biodiversity across East Africa. Afr. J. Environ. Sci. Technol., 3(10), 310-325. https://www.ajol.info/index.php/ajest/ article/view/56259

22. MWI. 1989-2017. Ministry of Water and IrrigationOpen files, Amman, Jordan.

23. Nagy R.C., Lockaby B.G., Helms B., Kalin L., Stoeckel D. 2011. Water resources and land use and cover in a humid region: the southeastern United States. J Environ Qual., DOI: 10.2134/jeq2010.0365

24. Shammout M.W. 2003. Land Use Options for Surface Water Management in Zarqa River Basin Using Modeling Tools. Ph.D. dissertation, The University of Jordan, Amman, Jordan.

25. Shammout M.W., Shatanawi M., Naber S. 2013. Participatory Optimization Scenario for Water Resources Management: A Case from Jordan. Water Resour. Manag., 27, 1949-1962. DOI: 10.1007/ s11269-013-0264-9

26. Shammout M.W., Shatanawi M., Nelson J. 2018. Curve Number Applications for Restoration the Zarqa River Basin. Sustainability, 10, 586. DOI: 10.3390/su10030586

27. Shatanawi M. \& Shammout M.W. 2011. Supplydemand modeling of water resources in Zarqa river basin in Jordan. Int. J. Appl. Environ. Sci., 6, 261-278.

28. Shanableh A., Al-Ruzouq R., Yilmaz A.G., Siddique M., Merabtene T., Imteaz M.A. 2018. Effects of Land Cover Change on Urban Floods and Rainwater Harvesting: A Case Study in Sharjah, UAE. Water, 10(5), 631. DOI: 10.3390/w10050631

29. Sriwongsitanon N. \& Taesombat W. 2011. Effects of land cover on runoff coefficient. Journal of Hydrology, 410(3-4), 226-238. DOI: 10.1016/j. jhydrol.2011.09.021

30. Xiong Y., Yin J., He F., Qiu G.Y. 2017. Effects of land use/land cover and climate changes on surface runoff in a semi-humid and semi-arid transition zone in northwest China. Hydrol. Earth Syst., Sci. 21, 183-196. DOI: 10.5194/hess-21-183-2017.

31. Xu P., Gao F., He J., Ren X., Xi W. 2017. Modeling and optimization of land use/land cover change in a developing urban catchment. Water Science and Technology, 75(11), 2527-2537. DOI: 10.2166/ wst.2017.401

32. Wrzesien M.L. \& Pavelsky T.M., 2020. Projected Changes to Extreme Runoff and Precipitation Events From a Downscaled Simulation Over the Western United States. Front. Earth Sci., 7, 355. DOI: $10.3389 /$ feart.2019.00355 